\title{
RESEARCH AND DEVELOPMENT AN ONLINE TRAINING COURSE TO ENHANCE TEACHER COMPETENCY IN CREATING DIGITAL MEDIA FOR TEACHING ENGLISH
}

\author{
AUTHOR \\ Wanida Simpol $^{1}$, Paulina ${ }^{2}$, Prakit Sinthong ${ }^{3}$, Phoom Praraksa ${ }^{4}$ \\ Loei Primary Educational Service Area Office $2^{1}$ \\ Universitas Muhammadiyah Gresik ${ }^{2}$ \\ Jiarawanon-Utis 4th School, Wangsaphung ${ }^{3}$ \\ Samutprakan Primary Educational Service Area Office $\mathbf{1}^{4}$ \\ Email: wanidaloei2@gmail.com $1,2,3,4$
}

\begin{abstract}
The education in the 21st century, which is a technology based paradigm, technology plays an important role to prepare English skills of learners. Teachers became facilitators to design learning activities and encourage them to grow their English competency through digital media so teachers need to develop their technology competency. This research aimed to develop an online training course to enhance teacher competency in creating digital media for teaching English in Loei Primary Educational Service Area Office 2, Thailand. Research and development methodology (R\&D) was applied for this study in the academic year 2020. There were 4 stages of research procedure consisted of 1) needs assessment, 2) creating of online training course, 3) trials phase, and 4) course evaluation. The participants were 71 English teachers selected from 189 English teachers in affiliated schools by G*Power software. The data were collected through questionnaires, tests and assessment form. Descriptive statistics were applied for quantitative data while one sample t-test and also dependent sample t-test were used for hypothesis testing. The result of this research indicated that the online training course reached the criteria of efficiency index and effectiveness index. In addition, it affected teachers' competency in creating digital media for teaching English with the statistical significance. The implication and recommendation were also discussed.
\end{abstract}

Keywords: Online Course, Digital Media, Teacher Development, English Teaching

\section{INTRODUCTION}

Technology plays an important role in education in the 21 st century, which is a technology based paradigm that uses technology to prepare learning skills. It has the nature of integrated learning to enhance learners' knowledge, skills, expertise and competencies in order to love learning for life including for the efficiency of learning for living in a changing society (Jirarat Prayurawong, 2019). In the era that information and communication technology plays an important role in every aspect of life, teachers have to change their thinking and adjust teaching methods in order to develop students with sufficient skills to live in the age of change quickly, timely and 
happily. For this reason, teachers must have competence in teaching management that is consistent with the context and needs of the digital age (Natthirat Peeraphan, 2020).

The 21st century learning teachers cannot be a teacher alone. It is imperative that students will be self-learners by teachers designing their learning to train themselves as coaches and facilitate them (Sasirada Pangthai, 2016). The use of digital media technology has made learning English faster, more convenient and easier than before, which is a traditional classroom where learners must use media and information content from teachers with an emphasis on lectures and narrators transfer knowledge to learners alone. Learners have a duty to receive knowledge from the teacher. This kind of teaching makes the students' English skill less or not as effective as they should be. The current teaching style has changed a lot from the way students take notes or listen to the teacher alone. Modern teaching and learning use to encourage learners to be more involved both by interacting with teaching and with classmates in a manner known as active learning (Wichai Puarungrote, Phatpong Pongphatthakan and Suchada Promkot, 2017). Nowadays, various technologies such as Information and Communication Technology (ICT), digital media and software are very important in language teaching. It is a tool for teachers to develop their own English language skills in order to become a model of language practice for learners, supporting learners' natural language learning as well as creating interaction, language imitation from native speakers, development of positive attitudes towards learning and practicing language skills (Chaiwat Kaewpan-ngam, 2016).

However, Thailand has faced the epidemic situation of the Coronavirus disease 2019 (COVID-19) since the beginning of 2020, resulting in educational institutions under the Ministry of Education have been closed for a long time (Ministry of Education, 2020). This have affected teaching and learning management including the development of teachers as defined in Act and rules of Office of the Teacher Civil Service and Educational Personnel Commission (OTEPC).

Because of the empirical evidence, concerned parties need to invent a model of teacher development that adheres to social distancing principles focusing on welfare and safety of teachers by developing online teacher training course. Not only solving the problem of teacher development in the epidemic situation of the Coronavirus Disease 2019, but also providing advantage for teachers. They can learn without limitations in time and place. Moreover, they can control the order of learning effectively. Furthermore, this online training course can be directly evaluated that help saving time and budget. The trainees able to review lessons and content at any time and able to ask questions or share ideas between participants and trainers. As a result, this study aimed to develop an online training course to enhance teacher competency in creating digital media for teaching English.

\section{METHODS}

Research and development methodology (R\&D) was applied for this research. There were 4 stages of research procedure consisted of 1) needs assessment, 2) creating of online training course, 3) trials phase, and 4) course evaluation. 


\section{a. Phase 1: Needs Assessment}

1) Participants

The population was 189 English teachers from affiliated schools of Loei Primary Educational Service Area Office 2, Thailand. The sample was 125 English teachers that was determined by Krejcie and Morgan formula at a 95\% of confidence level (Krejcie and Morgan, 1986 cited in Boonchom Srisaad, 2011). Stratified random sampling method was used was used to select the sample according to districts.

\section{2) Measures}

The tools used for collecting data was 5-level of rating scale questionnaire. The questionnaire form comprised of duo items that were degree of success and importance about teacher competency in creating digital media for teaching English. All items of the scale got 1.00 of IOC index that showing basic content validity of the research instrument with Cronbach Alpha Coefficient of 0.97 and 0.93 .

\section{3) Procedure and Design}

This step focused on online data collecting by 125 English teachers from affiliated schools of Loei PEASAO 2 during the first semester of academic year 2020.

\section{4) Data Analysis}

Descriptive statistics were applied for quantitative data from the questionnaire, and the Priority Need Index ( $\mathrm{PNI}_{\text {modified }}$ ) was statistics used for needs assessment of teacher competency in creating digital media for teaching English (Suwimol Vongvanich, 2005).

\section{b. Phase 2: Creating of Online Training Course}

\section{1) Participants}

The participant of this step were 5 experts in educational technology, teaching English and educational measurement and evaluation were obtained by purposive sampling.

\section{2) Measures}

The tools used for collecting data was 5-level of rating scale questionnaire. The questionnaire comprised of the 4 preliminary quality topics of the Online Training Course as utility feasibility, propriety and accuracy. The questionnaire was inspected inter rater reliability by Intra Class Correlation: ICC of 0.91.

\section{3) Procedure and Design}

The Online Training Course to Enhance Teacher Competency in Creating Digital Media for Teaching English was designed from needs assessment in phase 1 consisting of 8 topics of content as 1 . Creating test and exercise for practice 
English skills 2) Creating online meeting 3) Online interaction presentation 4) Creating games for kids 5) Presentation \& Emindmaps 6) Creating video for teaching English 7) Editing audio for listening task 8) Creating web board. There were 5 parts of the course component as 1) Course Description 2) Objectives 3) Learning Structure 4) Learning Process and 5) Learning Site. After finishing course creation the 5 experts evaluated the preliminary quality of the Online Training Course by online questionnaire.

\section{4) Data Analysis}

Descriptive statistics were applied for quantitative data from the questionnaire comprised of percentage, mean and Standard Deviations.

\section{c. Phase 3: Trial of the Online Training Course}

1) Participants

The participants of this part were 71 English teachers which registered for development. The sample size was determined using $\mathrm{G}^{*}$ Power program with an effect size of 0.3 and an error of 0.05 (Buchner, 2010 cited in Nongluck Wirachchai, 2012) and then selected by a simple random sampling technique.

2) Measures

The tools used for data collection were a pretest-posttest and a teacher's digital media creation assessment form. 20 items of multiple choices test was designed for the pretest-posttest with 0.8-1.00 of the Item of Objectives Congruence: IOC, $0.23-0.68$ of difficulty index, $0.46-0.82$ of discrimination index and 0.87 of reliability. The teacher's digital media creation assessment form indicated Intra Class Correlation: ICC of 0.96 that displayed the quality of psychometric property.

\section{3) Procedure and Design}

The online training course was tried out for 30 hours during January $4^{\text {th }}-$ March $10^{\text {th }}, 2021$. One group pretest-posttest design was applied to verify the efficiency and effectiveness of the innovation produced (Rattana Buason, 2011).

\section{4) Data Analysis}

The pretest-posttest scores were analyzed by percentage and mean. Then, the efficiency index (E1/E2) of the online training courses was calculated (Chaiyong Promwong, 2013). Next, the effectiveness index (E.I.) was also calculated (Rattana Buason, 2011). After that, pretest-posttest scores were compared by dependent sample t-test. In addition, the teachers' competency in creating digital media for teaching English was compared with a criteria score of $70 \%$.

\section{d. Phase 4: The evaluation of the Online Training Course}

\section{1) Participants}

The participants of this part were 71 English teachers which registered for development. The sample size was determined using $\mathrm{G}^{*}$ Power program with 
an effect size of 0.3 and an error of 0.05 (Buchner, 2010 cited in Nongluck Wirachchai, 2012) and then selected by a simple random sampling technique.

2) Measures

The tools used for collecting data was 5-level of rating scale questionnaire. The questionnaire form comprised of 7 items for making decision about the final quality of the online training course. All items of the scale got 1.00 of IOC index that showing basic content validity of the research instrument with Cronbach Alpha Coefficient of 0.95 .

\section{3) Procedure and Design}

The online training course was judged by the participants through the online questionnaire after the trial phase finished.

\section{4) Data Analysis}

Descriptive statistics were applied for quantitative data from the questionnaire comprised of percentage, mean and Standard Deviations.

\section{RESULT AND DISCUSSION}

\section{a. Need Assessment of Teacher Development}

The Priority Need Index indicated that the teachers needed to enhance their competency of Creating Digital Media for Teaching English in 8 topics with $0.33-0.57$ of $\mathrm{PNI}_{\text {modified. They }}$ comprised of 1) 1. Creating test and exercise for practice English skills 2) Creating games for kids 3) Online interaction presentation 4) Creating online meeting 5) Creating video for teaching English 6) Presentation \& Emindmaps 7) Creating web board and 8) Editing audio for listening task respectively.

\begin{tabular}{|c|c|c|c|c|c|c|}
\hline \multirow{2}{*}{ Topics } & \multicolumn{2}{|c|}{ Degree of success } & \multicolumn{2}{|c|}{ Importance } & \multirow[t]{2}{*}{$\mathrm{PNI}_{\text {modified }}$} & \multirow{2}{*}{$\begin{array}{r}\text { Selected/ } \\
\text { Priority }\end{array}$} \\
\hline & Mean & S.D. & Mean & S.D. & & \\
\hline 1. Creating test and exercise for practice English skills & 2.88 & 0.24 & 4.53 & 0.34 & 0.57 & yes/1 \\
\hline 2. Creating online meeting & 2.85 & 0.02 & 4.35 & 0.12 & 0.53 & yes/4 \\
\hline 3. Online interaction presentation & 2.79 & 0.21 & 4.29 & 0.31 & 0.54 & yes/3 \\
\hline 4. Creating games for kids & 2.88 & 0.15 & 4.48 & 0.25 & 0.56 & yes $/ 2$ \\
\hline 5. Presentation \& Emindmaps & 3.17 & 0.11 & 4.47 & 0.21 & 0.41 & yes/6 \\
\hline 6. Creating video for teaching English & 2.95 & 0.14 & 4.45 & 0.24 & 0.51 & yes/5 \\
\hline 7. Editing audio for listening task & 3.31 & 0.23 & 4.41 & 0.33 & 0.33 & yes/8 \\
\hline 8. Creating web board & 3.28 & 0.31 & 4.38 & 0.41 & 0.34 & yes/7 \\
\hline 9. Applying email for teaching & 3.90 & 0.55 & 3.92 & 0.65 & 0.01 & no \\
\hline 10. Creating website & 3.86 & 0.43 & 3.98 & 0.53 & 0.03 & no \\
\hline
\end{tabular}

* $\mathrm{PNI}_{\text {modified }}>0.30$ was selected

Table 1. Need Assessment of Teacher Development

\section{b. An Online Training Course to Enhance Teacher Competency in Creating Digital Media for Teaching English}

The Online Training Course to Enhance Teacher Competency in Creating Digital Media for Teaching English consisted of 5 parts as 1) Course Description 2) Objectives 3) Learning Structure 4) Learning Process and 5) Learning Site. 


\section{1) Course Description}

The Training Curriculum of Digital Media Creating for Teaching English is an online training course concerning the applying program, software and application to create digital media creating for teaching English. The content consists of creating multiple choices task, short answer task, cross puzzle, cloze passage task, matching task, scrambled sentences task for English skills practice. In addition, it also contains creating games for kids and quiz, designing our own template in power point, creating simple presentation, online meeting, interaction presentation, creating video for teaching English, editing audio for listening task, and web board.

2) Objectives

a) To develop English teachers knowledge and ability to use technology for education by using program, software, and applications to create digital media for teaching English.

b) To encourage teachers who succeed the training produce interesting digital teaching materials along the trend of learning in the $21^{\text {st }}$ century that focuses on English communication skills and digital ability of learners.

\section{3) Learning Structure}

\begin{tabular}{|c|c|c|c|c|c|}
\hline Unit & Content & $\begin{array}{c}\text { Program/Software/ } \\
\text { Application }\end{array}$ & Objectives & $\begin{array}{c}\text { Learning Activities \& } \\
\text { Assessment }\end{array}$ & $\begin{array}{c}\text { Time } \\
\text { (hours) }\end{array}$ \\
\hline $\begin{array}{l}\text { Learners Analysis } \\
\text { Dr. Wanida Simpol }\end{array}$ & Pretest & Google Form & $\begin{array}{l}\text { To check the learners } \\
\text { background knowledge }\end{array}$ & Online test & 1 \\
\hline $\begin{array}{l}\text { 1. Creating test } \\
\text { and exercise for } \\
\text { practice English } \\
\text { Skills } \\
\text { Miss Paulina M.Pd. }\end{array}$ & $\begin{array}{l}\text { 1. Creating multiple choices } \\
\text { task } \\
\text { 2. Creating short answer } \\
\text { task } \\
\text { 3. Creating cross puzzle } \\
\text { 4. Creating cloze passage } \\
\text { task } \\
\text { 5. Creating matching task } \\
\text { 6. Creating scrambled } \\
\text { sentences task }\end{array}$ & Hot Potatoes & $\begin{array}{l}\text { 1. Able to create multiple } \\
\text { choices task } \\
\text { 2. Able to create short answer } \\
\text { task } \\
\text { 3. Able to create cross puzzle } \\
\text { 4. Able to create cloze } \\
\text { passage task } \\
\text { 5. Able to create matching } \\
\text { task } \\
\text { 6. Able to create scrambled } \\
\text { sentences task }\end{array}$ & $\begin{array}{l}\text { 1. Study video clip } \\
\text { 2. Study online content } \\
\text { 3. Discuss with friends via } \\
\text { online system } \\
\text { 4. Assignment and } \\
\text { Dissemination }\end{array}$ & 6 \\
\hline $\begin{array}{l}\text { 2. Creating Online } \\
\text { Meeting } \\
\text { Dr. Prakit Sinthong } \\
\text { Dr. Phoom Praraksa }\end{array}$ & $\begin{array}{l}\text { 1. Creating Online Meeting } \\
\text { via Zoom } \\
\text { 2. Creating Online Meeting } \\
\text { via Google Meet }\end{array}$ & $\begin{array}{l}\text { Zoom } \\
\text { Google Meet }\end{array}$ & $\begin{array}{l}\text { Able to create and join } \\
\text { meeting via Zoom and } \\
\text { Google Meet }\end{array}$ & $\begin{array}{l}\text { 1. Study video clip } \\
\text { 2. Study online content } \\
\text { 3. Discuss with friends via } \\
\text { Zoom } \\
\text { Google Meet }\end{array}$ & 2 \\
\hline $\begin{array}{l}\text { 3. Online } \\
\text { Interaction } \\
\text { Presentation } \\
\text { Dr. Wanida Simpol }\end{array}$ & $\begin{array}{l}\text { 1. Interaction survey } \\
\text { 2. Brainstorming }\end{array}$ & Mentimeter & $\begin{array}{l}\text { Able to create Interaction } \\
\text { survey and Brainstorming }\end{array}$ & $\begin{array}{l}\text { 1. Study video clip } \\
\text { 2. Study online content } \\
\text { 3. Discuss with friends via } \\
\text { online system } \\
\text { 4. Assignment and } \\
\text { Dissemination }\end{array}$ & 2 \\
\hline $\begin{array}{l}\text { 4. Creating games } \\
\text { Miss Paulina M.Pd. } \\
\text { Dr. Prakit Sinthong }\end{array}$ & $\begin{array}{l}\text { 1. Creating games for kids } \\
\text { 2. Creating Quiz }\end{array}$ & $\begin{array}{l}\text { Hangaroo } \\
\text { Kahoot }\end{array}$ & $\begin{array}{l}\text { 1. Able to create games for } \\
\text { kids } \\
\text { 2. Able to create Quiz by } \\
\text { Kahoot }\end{array}$ & $\begin{array}{l}\text { 1. Study video clip } \\
\text { 2. Study online content } \\
\text { 3. Discuss with friends via } \\
\text { online system } \\
\text { 4. Assignment and } \\
\text { Dissemination }\end{array}$ & 4 \\
\hline $\begin{array}{l}\text { 5. Presentation } \\
\text { Miss Paulina M.Pd. }\end{array}$ & $\begin{array}{l}\text { 1. Designing our own } \\
\text { template in power point } \\
\text { 2. creating simple } \\
\text { presentation }\end{array}$ & $\begin{array}{l}\text { Slide master } \\
\text { Emindmaps }\end{array}$ & $\begin{array}{l}\text { 1. Able to design our own } \\
\text { template in power point } \\
\text { 2. Able to create simple } \\
\text { presentation }\end{array}$ & $\begin{array}{l}\text { 1. Study video clip } \\
\text { 2. Study online content } \\
\text { 3. Discuss with friends via } \\
\text { online system }\end{array}$ & 4 \\
\hline
\end{tabular}


UMGCINMATIC : $1^{\text {st }}$ Rethinking Education during Covid-19 Era: Challange and Innovation Volume 1 No 2

\begin{tabular}{|c|c|c|c|c|c|}
\hline Unit & Content & $\begin{array}{c}\text { Program/Software/ } \\
\text { Application }\end{array}$ & Objectives & $\begin{array}{c}\text { Learning Activities \& } \\
\text { Assessment }\end{array}$ & $\begin{array}{c}\text { Time } \\
\text { (hours) }\end{array}$ \\
\hline & & & & $\begin{array}{l}\text { 4. Assignment and } \\
\text { Dissemination }\end{array}$ & \\
\hline $\begin{array}{l}\text { 6. Creating video } \\
\text { for teaching } \\
\text { English }\end{array}$ & $\begin{array}{l}\text { Creating video for teaching } \\
\text { English }\end{array}$ & Power Point & $\begin{array}{l}\text { Able to create video for } \\
\text { teaching English }\end{array}$ & $\begin{array}{l}\text { 1. Study video clip } \\
\text { 2. Study online content } \\
\text { 3. Discuss with friends via } \\
\text { online system }\end{array}$ & 2 \\
\hline Dr. Wanida Simpol & & & & $\begin{array}{l}\text { 4. Assignment and } \\
\text { Dissemination }\end{array}$ & \\
\hline $\begin{array}{l}\text { 7. Editing audio for } \\
\text { listening task } \\
\text { Miss Paulina M.Pd. }\end{array}$ & $\begin{array}{l}\text { Editing audio for listening } \\
\text { task }\end{array}$ & Adobe Audition & $\begin{array}{l}\text { Able to edit audio for } \\
\text { listening task }\end{array}$ & $\begin{array}{l}\text { 1. Study video clip } \\
\text { 2. Study online content } \\
\text { 3. Discuss with friends via } \\
\text { online system } \\
\text { 4. Assignment and } \\
\text { Dissemination }\end{array}$ & 2 \\
\hline $\begin{array}{l}\text { 8. Creating web } \\
\text { board } \\
\text { Dr. Wanida Simpol }\end{array}$ & Creating web board & Padlet & Able to create web board & $\begin{array}{l}\text { 1. Study video clip } \\
\text { 2. Study online content } \\
\text { 3. Discuss with friends via } \\
\text { online system } \\
\text { 4. Assignment and } \\
\text { Dissemination }\end{array}$ & 2 \\
\hline $\begin{array}{l}\text { Evaluation } \\
\text { Dr. Wanida Simpol }\end{array}$ & Posttest & Google Form & $\begin{array}{l}\text { To evaluate the knowledge } \\
\text { and ability of learners }\end{array}$ & Online test & 1 \\
\hline \multicolumn{5}{|c|}{ Total } & 26 \\
\hline
\end{tabular}

Table 2. Learning Structure of the Online Training Course

\section{4) Learning Process}

The learning process started at online applying then registration. After that, the trainees created their communicative group to help and share ideas. Before starting the lesson, they had to do online pretest. Then, they learned the content and joined activities by themselves on the learning site of the course. During the course, they need to meet the communicative group once to discussion learning progress and also problems. Finally, they did a posttest. If they pass the test they will get a certificate. However, if they could not pass the test, they were requested to relearn the course again. 


\section{Learning Process}

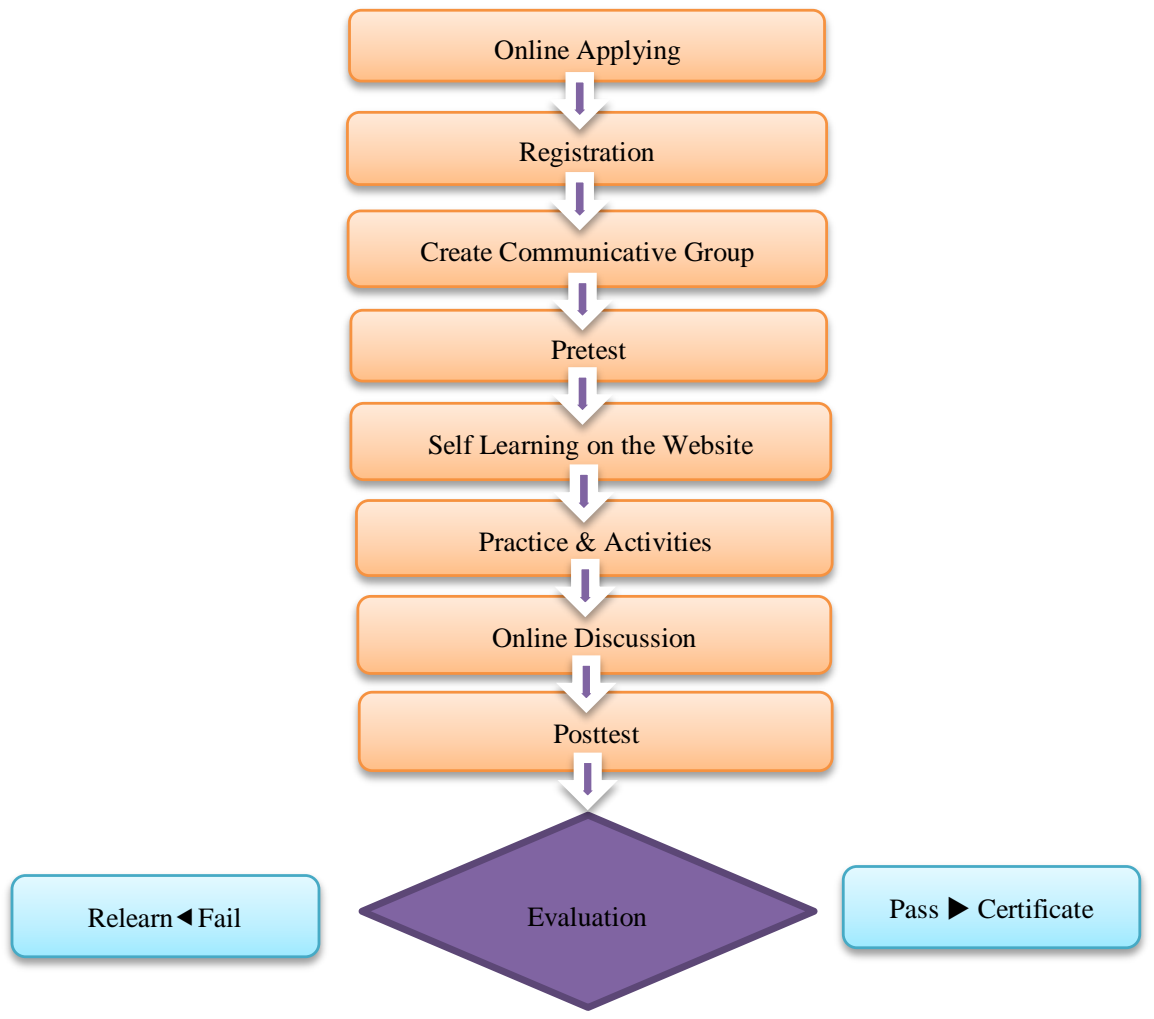

Picture 1. Learning Process of the Online Training Course to Enhance Teacher Competency in Creating Digital Media for Teaching English

5) The learning site of the Online Training Course to Enhance Teacher Competency in Creating Digital Media for Teaching English

The learning site of the Online Training Course to Enhance Teacher Competency in Creating Digital Media for Teaching English created by Google Site as follow;

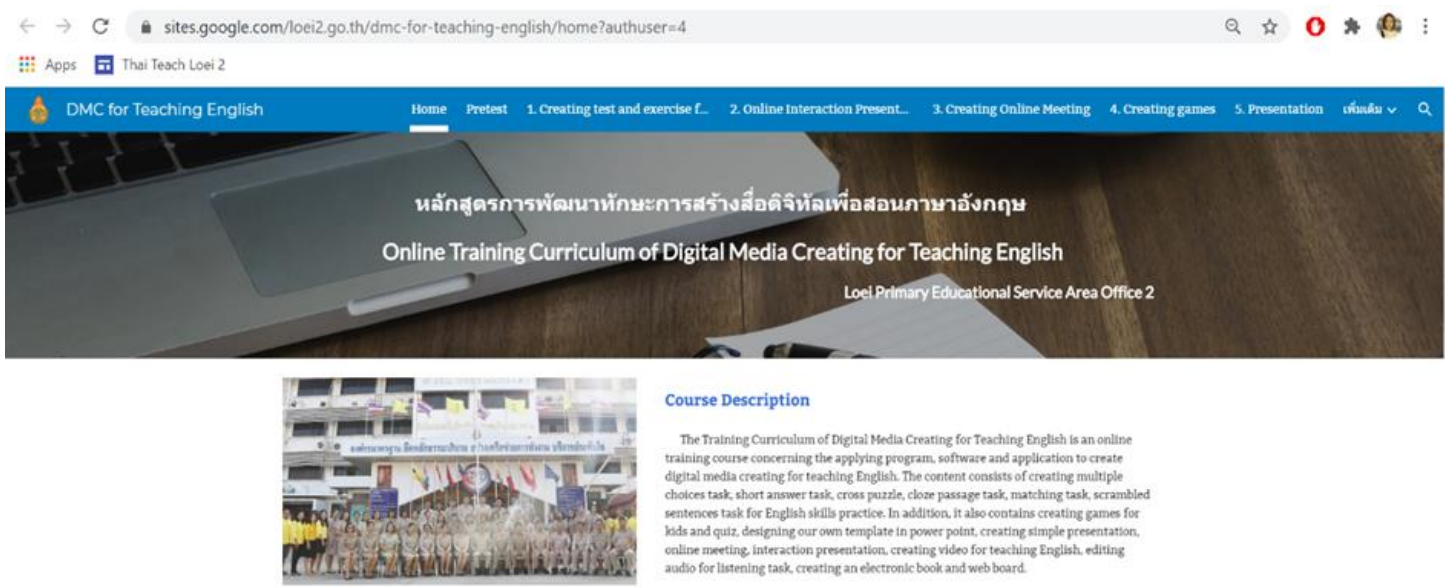




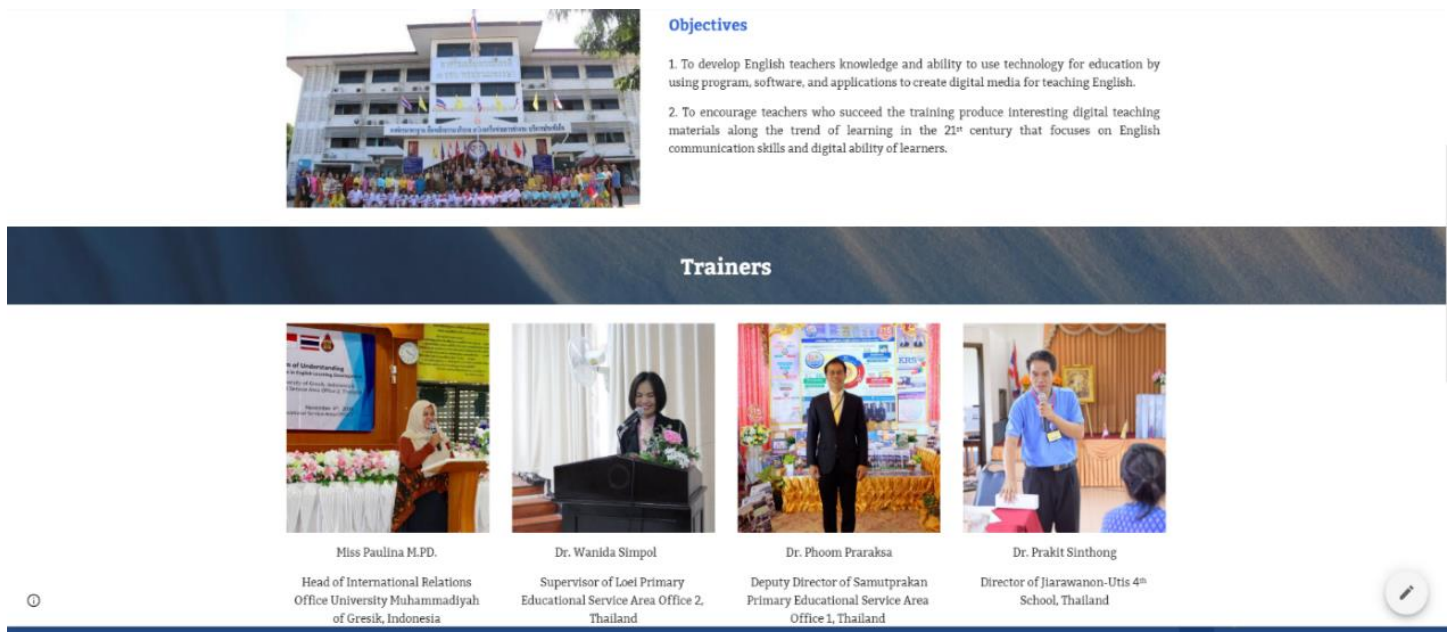

Picture 3. Learning Site of the Online Training Course to Enhance Teacher Competency in Creating Digital Media for Teaching English

\section{c. The Preliminary Quality of The Online Training Course}

The preliminary quality of the Online Training Course to Enhance Teacher Competency in Creating Digital Media for Teaching English was at a high level overall. In addition, the Utility, Feasibility, Propriety and Accuracy were also at a high level. This showed the high quality of the Online Training Course.

\begin{tabular}{lccc}
\hline \multicolumn{1}{c}{ Items } & \multicolumn{3}{c}{ Evaluation } \\
\cline { 2 - 5 } & Mean & S.D. & Level \\
\hline Utility & $\mathbf{4 . 3 4}$ & $\mathbf{0 . 0 7}$ & high \\
1. The course content is useful for improving teachers' English teaching. & 4.32 & 0.65 & high \\
2. This training provides teachers with guidelines for developing digital & 4.25 & 0.64 & high \\
media. & & & \\
3. Teachers have more media for teaching English. & 4.41 & 0.62 & high \\
4. Teachers have developed skills in using technology for education. & 4.37 & 0.63 & High
\end{tabular}

\begin{tabular}{|l|c|c|c|}
\hline \multicolumn{1}{|c|}{ Items } & \multicolumn{3}{c|}{} \\
\cline { 2 - 4 } & Mean & S.D. & Level \\
\hline Feasibility & $\mathbf{3 . 9 0}$ & $\mathbf{0 . 0 7}$ & high \\
\hline 5. The training content can be practical. & 3.95 & 0.87 & high \\
\hline 6. Teachers can use their knowledge to develop English teaching materials. & 3.81 & 0.92 & high \\
\hline 7. Teachers can create digital media as required by the curriculum. & 3.96 & 0.95 & high \\
\hline 8. The technology used to create the media is easily accessible. & 3.88 & 0.89 & high \\
\hline Propriety & $\mathbf{4 . 0 5}$ & $\mathbf{0 . 0 2}$ & high \\
\hline 9. The training content is up-to-date in accordance with the current situation. & 4.02 & 0.79 & high \\
\hline 10. The content of the training is consistent with the teachers' need. & 4.06 & 0.89 & high \\
\hline 11. The training processes and activities are appropriate. & 4.07 & 0.86 & high \\
\hline 12. The duration of the training is appropriate. & 4.05 & 0.85 & high \\
\hline Accuracy & $\mathbf{4 . 0 1}$ & $\mathbf{0 . 1 1}$ & high \\
\hline 13. The online training course is correct with the principles and theory. & 4.04 & 0.79 & high \\
\hline 14. The online training course is congruent with the organization policy. & 4.06 & 0.74 & high \\
\hline 15. The content of the online training course is completed. & 4.09 & 0.80 & high \\
\hline 16. The online training course covers the necessary content. & 3.85 & 0.91 & high \\
\hline
\end{tabular}


UMGCINMATIC : $1^{\text {st }}$ Rethinking Education during Covid-19 Era: Challange and Innovation Volume 1 No 2

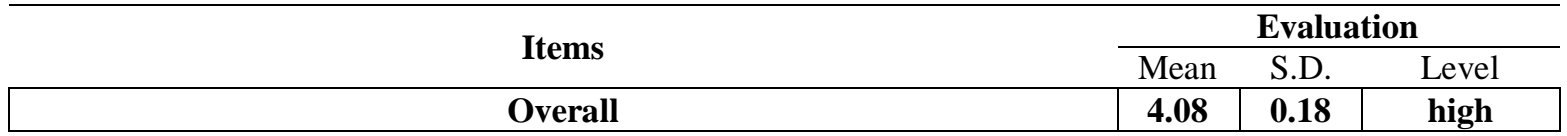

Table 3. The preliminary quality of the Online Training Course

\section{d. The Trial Results of the Online Training Course}

1) The Efficiency and Effectiveness of the Online Training Course

The Efficiency Index of the Online Training Course shown 84.35/83.91 of E1/E2 with the Effectiveness Index of 0.8364. That meant The Trial results of the Online Training Course achieved the criteria.

\begin{tabular}{cccccc}
\hline $\begin{array}{c}\text { Pretest } \\
(\%)\end{array}$ & $\begin{array}{c}\text { Posttest } \\
(\%)\end{array}$ & $\begin{array}{c}\text { Process } \\
\text { Efficiency }(\%)\end{array}$ & $\begin{array}{c}\text { Outcome } \\
\text { Efficiency }(\%)\end{array}$ & E1/E2 & E.I. \\
\hline 52.01 & 92.15 & 84.35 & 83.91 & $84.35 / 83.91$ & 0.8364
\end{tabular}

Table 4. The Efficiency and Effectiveness of the Online Training Course

2) The teacher competency in creating digital media for teaching English.

Comparison of digital literacy scores in creating digital media for teaching English before and after studying with the online training course found that the teachers post test scores were statistically higher than before at the .01 level of significant displayed as table 4. In addition, the comparison of scores in creating digital media for teaching English found that the teachers had an average score of 89.31 percent for creating digital media which was higher than the score of 70 percent with statistical significance at the .01 level displayed as table 5 .

\begin{tabular}{lcccccccc}
\hline \multirow{2}{*}{ Scores } & \multicolumn{2}{c}{ Pretest (Full 20) } & \multicolumn{2}{c}{ Posttest (Full 20) } & \multirow{2}{*}{ df } & df & $\mathrm{t}$ \\
\cline { 2 - 5 } & Mean & S.D. & Mean & S.D. & & & \\
\hline $\begin{array}{l}\text { Digital literacy in creating } \\
\text { digital media for teaching }\end{array}$ & 10.41 & 5.40 & 18.43 & 1.79 & 71 & 70 & $19.900^{* *}$ \\
English & & & & & & & \\
\hline
\end{tabular}

Mark ** statistical significance at the .01 level

Table 5. The comparison of digital literacy scores in creating digital media for teaching English

\begin{tabular}{|c|c|c|c|c|c|c|}
\hline \multirow{2}{*}{ Scores } & \multicolumn{2}{|c|}{ Scores $(\%)$} & \multirow{2}{*}{$\begin{array}{c}\text { Criteria } \\
\text { Percentage }\end{array}$} & \multirow{2}{*}{$\mathrm{n}$} & \multirow{2}{*}{ df } & \multirow{2}{*}{$\mathrm{t}$} \\
\hline & Mean & S.D. & & & & \\
\hline $\begin{array}{l}\text { Teacher competency in creating } \\
\text { digital media for teaching English }\end{array}$ & 89.31 & 17.13 & 70 & 71 & 70 & $15.118 * *$ \\
\hline
\end{tabular}

Table 6. The comparison of teacher competency in creating digital media for teaching English to the criteria of $70 \%$ 


\section{e. The evaluation of the Online Training Course}

The evaluation of the Online Training Course found that overall, the teachers who participated the development agreed that the online training course was appropriate at a high level. The teachers are convenient when studying online training course is the highest. They agreed on the method of development in the form of online training. Moreover, they have increased knowledge and understanding of using digital media for teaching respectively.

\begin{tabular}{lccc}
\hline \multicolumn{1}{c}{ Items } & \multicolumn{3}{c}{ Evaluation } \\
\cline { 2 - 4 } & Mean & S.D. & Level \\
\hline $\begin{array}{l}\text { 1. The content of the online training course is easy to understand and not } \\
\text { complicated. }\end{array}$ & 4.36 & 0.27 & high \\
$\begin{array}{l}\text { 2. The teachers are convenient when studying online training course. } \\
\text { 3. The teachers agree on the method of development in the form of online } \\
\text { training. }\end{array}$ & 4.71 & 0.28 & highest \\
$\begin{array}{l}\text { 4. The teachers have increased knowledge and understanding of using digital } \\
\text { media for teaching. }\end{array}$ & 4.43 & 0.33 & highest \\
$\begin{array}{l}\text { 5. The teachers can create digital materials to teach English. } \\
\text { 6. The teachers can pass on their knowledge to others after completing an } \\
\text { online training course. }\end{array}$ & 4.18 & 0.67 & high \\
\begin{tabular}{l} 
7. The teachers are satisfied with the online training course as a whole. \\
\multicolumn{1}{c}{ Overall }
\end{tabular} & 4.43 & 0.23 & high \\
\hline
\end{tabular}

Table 7. The evaluation of the Online Training Course

\section{CONCLUSION}

\section{a. Need assessment of teacher development}

The Priority Need Index indicated that the teachers needed to enhance their competency of Creating Digital Media for Teaching English in 8 topics with $0.33-0.57$ of $\mathrm{PNI}_{\text {modified. }}$ They comprised of 1) 1. Creating test and exercise for practice English skills 2) Creating games for kids 3) Online interaction presentation 4) Creating online meeting 5) Creating video for teaching English 6) Presentation \& Emindmaps 7) Creating web board and 8) Editing audio for listening task respectively. This is because the use of technology and digital media has made learning English faster, more convenient and easier. Nowadays, various technologies such as Information and Communication Technology (ICT), digital media and software play a significant role in language teaching. It is a tool to practice important language skills for teachers to develop their English skills in order to be a model of language training for learners including supporting learners' language learning naturally. In addition, technologies help promote interaction, language imitation from a native speaker and develop a positive attitude towards learning and practicing language skills (Chaiwat Kaewpan-ngam, 2016).

b. An Online Training Course to Enhance Teacher Competency in Creating Digital Media for Teaching English

The Online Training Course to Enhance Teacher Competency in Creating Digital Media for Teaching English consisted of 5 parts as 1) Course Description 2) Objectives 3) Learning Structure 4) Learning Process and 5) Learning Site. The preliminary quality of the Online Training Course was at a high level overall. In addition, the Utility, 
Feasibility, Propriety and Accuracy were also at a high level. This showed the high quality of the Online Training Course.This is consistent with the research results of Emika Wachirawin, Ritthichai Onming, Laddawan Kasemnet \& Duangjai Sikheaw (2017) who studied the effectiveness of an online training course on web 2.0 application in the classroom using theory of online collaborative learning to promote teachers' ICT competency. The result found that the online training course consisted of 5 learning units. The results of the study on the efficiency of the curriculum were passed the criteria for the innovation media assessment. There was a conformity index and the suitability quality of the draft curriculum was very good.

\section{c. The Trial results of the Online Training Course}

The Efficiency Index of the Online Training Course shown 84.35/83.91 of E1/E2 with the Effectiveness Index of 0.8364 . That meant The Trial results of the Online Training Course achieved the criteria. In addition, the comparison of digital literacy scores in creating digital media for teaching English before and after studying with the online training course found that the teachers post test scores were statistically higher than before at the .01 level of significant displayed as table Furthermore, the comparison of scores in creating digital media for teaching English found that the teachers had an average score of 89.31 percent for creating digital media which was higher than the score of 70 percent with statistical significance at the .01 level displayed as table 5 . This may be due to the fact that the online training courses created are quality checked for content validity that meets the criteria and are reviewed for suitability by experts. There was also a performance test which showed that the online teacher training course was effective as a benchmark. In terms of effectiveness, it was also shown that online training courses helped teachers reach $89.31 \%$ improvement in achievement scores. This is accordance with the research results of Jerdchan Phondongnok (2013) has developed an online training system for coaching for service providers who use commercial bank technology. The results showed that content and online training system quality is at a good level. Likewise the scores after the training of the officers were significantly higher than before the training at the .05 level.

\section{d. The evaluation of the Online Training Course}

The evaluation of the Online Training Course found that overall the teachers who participated the development agreed that the online training course was appropriate at a high level. The teachers are convenient when studying online training course is the highest. They agreed on the method of development in the form of online training. Moreover, they have increased knowledge and understanding of using digital media for teaching respectively. This is consistent with the research results of Emika Wachirawin, Ritthichai Onming, Laddawan Kasemnet \& Duangjai Sikheaw (2017) who studied the effectiveness of an online training course on web 2.0 application in the classroom using theory of online collaborative learning to promote teachers' ICT competency. The results showed that the results of the study on the efficiency of the curriculum were 
passed the criteria for the innovation media assessment. There was a conformity index and the suitability quality of the draft curriculum was very good.

\section{e. Recommendation}

The results of this research reflect that as the world situation changes, teachers need to adjust. This is not only to modify the teaching style, but also change the model of selfdevelopment in accordance with the situation in order to develop effective teaching. Therefore, online training is a form of teacher development that is efficient, convenient, and easy to access. Moreover, the cost will be saved which relevant organizations should be used as an alternative for teacher development. However, online development requires quality control of development to meet the standards. Therefore, interactions between facilitators and participants are also an important part of ensuring progress and control the quality of teacher development. Two-way communication by online group meetings should be used to verify this quality. In the next research, the online training system should be developed in other content to provide teachers with various channels for self-development. It is easily accessible, convenient and congruent with the development needs of teachers.

\section{References}

Boonchom Srisa-ad. (2011). Basic Research. $9^{\text {th }}$ ed. Bangkok : Suwiriyasan.

Chaiwat Kaewpan-Ngam. (2016). Technology for Assessing Language Learning for $21^{\text {st }}$ Century Learners. Veridian E-Journal, Silpakorn University, 9(3), 436-452.

Chaiyong Brahmawong. (2013). Developmental Testing of Media and Instructional Package.

Silapakorn Educational Research Journal, 5(1), 5-20.

Emika Wachirawin, Ritthichai Onming, Laddawan Kasemnet \& Duangjai Sikheaw. (2017).

Efficacy Study Online training course on Web 2.0 application in the classroom using collaborative learning theory on Online to promote ICT competency of teachers.

Journal of Education Faculty of Education Srinakharinwirot University, 18(1), 182

197.

Government Teacher and Educational Personnel Regulation Act, B.E. 2547

(December 23 $3^{\text {th }}$, 2004). Government Gazette. Volume 121, chapter $79 \mathrm{~g}$.

Jerdchan Phondongnok. (2013). Development of an online training system of coaching jobs for service providers who use commercial bank technology. Veridian E-Journal,

SU Humanities Group, and Social Sciences, 6 (1), 385-398.

Jirarat Prayurawong. (2019). DIGITAL LEARNING Learning English in the digital world

in the 21st century. Graduate Studies Journal, Valaya Alongkorn Rajabhat

University Under the Royal Patronage, 13(1), 210-223.

Ministry of Education. (2020). Announcement of the Ministry of Education regarding the opening of educational institutions under the supervision of the Ministry of

Education. Retrieved April 10 ${ }^{\text {th }}, 2020$, from https://moe360.blog/2020/04/09

National Education Act 1999. (19 August 1999). Government Gazette. Volume 116, chapter 74 
g.

Natteerat Peeraphan. (2020). Competency for teacher in digital age. Retrieved October 15, 2020, from https://lms.thaimooc.org/courses/course-v1:SWU+SWU006+2017/about Nongluck Wiratchai. (2012). Usable Statistics. $2^{\text {nd }}$ ed. Bangkok: Icon Printing.

Rattana Buason. (2011). Research and Development of Educational Innovations. $2^{\text {nd }}$ ed. Nakhon Sawan : Rimping Printing.

Sasirada Pangthai. (2016). The Role of School Administrators in the 21st Century.

Asian Graduate College Journal, 6(1), 7-11.

Suwimol Vongvanich. (2005). Needs Assessment Research. Bangkok : Thammada Press.

Teacher Civil Service and Educational Personnel Commission (OTEPC). (2019). Office book OTEPC. No. 0206.7/81 dated March $25^{\text {th }}, 2019$, titled curriculum for the development of teachers and educational personnel of teaching field. Retrieved May $1^{\text {st }}, 2020$ from https://circular62.otepc.go.th/

Wichai Puarungrote, Phatphong Pongpattakarn, and Suchada Promkot. (2017). Trends in teaching and learning methods in a new era with an online assessment tool. Journal of Learning Innovations, Walailak University, 3 (2), 45-68. 